http://jmscr.igmpublication.org/home/ ISSN (e)-2347-176x ISSN (p) 2455-0450 crossref DOI: https://dx.doi.org/10.18535/jmscr/v8i2.51

\title{
Incidence of Cardiogenic Shock in Acute Stemi Patients Thrombolysed with Streptokinse
}

\author{
Authors \\ Dr Uddhav Khaire ${ }^{1}$, Dr. Rahul Rathod ${ }^{2}$, Dr Shweta Shinde ${ }^{3}$ \\ ${ }^{1}$ Associate Professor, Govt. Medical College Aurangabad \\ ${ }^{2}$ Assistant Professor, Govt. Medical College, Aurangabad \\ ${ }^{3}$ Junior Resident, Govt. Medical College, Aurangabad
}

\begin{abstract}
Introduction: Thrombolysis therapy in randomized controlled trials has shown to improve the natural history of acute myocardial infarction with approximate $30 \%$ reduction in mortality. Non-invasive detection of reperfusion is an useful guide for future management. Resolution of ST segment elevation following thrombolytic therapy has been shown to be a simple and useful predictor of left ventricular function and clinical outcome. Reduction in ST segment elevation, relief from chest pain, early peaking of serum concentration of creatine kinase and reperfusion arrhythmias are some of the non-invasive markers of reperfusion. ${ }^{l}$
\end{abstract}

Farrer $M$ et al. suggested that previous studies have shown an association between each resolution of ST elevation after thrombolysis and improved coronary patency and clinical outcome. ${ }^{2}$ Thrombolytic therapy for acute myocardial infarction reduces case fatality and improves clinical outcomes. ${ }^{5,6}$

Material and Methods: We conducted cross sectional observational study in 200 patients of acute ST segment elevation myocardial infarction. Outcome of early (within 6 hours) and late (after 6 hours) thrombolysis in patients of STEMI studied and compared.

Results: About the complication after receiving thrombolytic therapy $37 \%$ were in cardiogenic shock, 27.5 $\%$ land up in CCF, 15\% showed arrhythmias. most of cases 85 (42.5\%)ST segment resolution > 50\% were seen where there is initiation of therapy before 6 hours, whereas only 41 (20.5\%) of cases shows improve ST segment $>50 \%$ after 6 hours of initiation of therapy.

Conclusion: Complication like cardiogenic shock were significantly less in patients thrombolysed within 6 hours of onset of chest pain compared to those who thrombolysed after 6 hours.

\section{Introduction}

Thrombolysis therapy in randomized controlled trials has shown to improve the natural history of acute myocardial infarction with approximate $30 \%$ reduction in mortality. Non-invasive detection of reperfusion is an useful guide for future management. Resolution of ST segment elevation following thrombolytic therapy has been shown to be a simple and useful predictor of left ventricular function and clinical outcome.
Primary goal of therapy in ST elevation myocardial infarction has been to restore normal blood flow in the occluded epicardial coronary artery as rapidly as possible. Early and sustained patency of infarct related artery is necessary, to ensure optimal outcome of reperfusion therapy. So optimal goal of reperfusion therapy is to establish nutrient blood flow at tissue level.

Reduction in ST segment elevation, relief from chest pain, early peaking of serum concentration 
of creatine kinase and reperfusion arrythmias are some of the non-invasive markers of reperfusion. ${ }^{1}$ Farrer $\mathrm{M}$ et al. suggested that previous studies have shown an association between each resolution of ST elevation after thrombolysis and improved coronary patency and clinical outcome. ${ }^{2}$ Since 1987 Anthon K et al. work on critical role of coronary thrombosis in acute myocardial infarction has been confirmed. This provides the scientific basis for thrombolytic therapy, the advent of which has been the cause of much global excitement and revolutionized the treatment of AMI. ${ }^{3}$

In acute myocardial infarction, early identification of patients at a high mortality risk is important for planning further therapeutic strategies. Previous studies have demonstrated that the extent of early resolution of ST-segment elevation may represent a simple, quick and noninvasive assessment to identify high risk groups of patients. ${ }^{4}$

Thrombolytic therapy for acute myocardial infarction reduces case fatality and improves clinical outcomes. ${ }^{5,6}$

By contrast, ST segment resolution 90-180 minutes after thrombolysis is an excellent marker of successful myocardial reperfusion ${ }^{7}$ and a strong predictor of survival and preservation of left ventricular function. ${ }^{8-10}$

In most regions in the world in general, and in Europe in particular, thrombolytic therapy is still the fastest and best accessible reperfusion treatment for most patients presenting with acute STEMI, as indicated in the international guidelines. ${ }^{11-12}$

The thrombolytic agent used in our study is streptokinase.

\section{Material and Methods}

A cross sectional observational study at a tertiary healthcare hospital. The study was conducted after formal approval from institutional ethics committee. The study was conducted with 200 patients of acute STEMI including diagnosed cases of Acute ST elevated myocardial infarction as per WHO criteria requiring at least 2 of following 3 elements to be present1.History of ischemic type of chest pain (resting chest pain lasting for more than 30 minutes). 2.Evolutionary change on serially obtained ECG tracings (atleast $2 \mathrm{~mm}$ in adjacent chest leads and/or ST segment elevation at least $1 \mathrm{~mm}$ in 2 or more standard leads)3. A rise of serum cardiac markers. Patients who are eligible for the study and who received streptokinase and patients above 18 years of age excluding patients Below 18 years of age, Those patients who are not willing, Patients with recent history of stroke, active bleeding, recent major operation, recent non compressible vascular puncture, previous treatment with streptokinase and patient those who have contraindication for thrombolytic therapy.

The demographic features of patients were recorded which included age, sex, date admission, date of discharge, date of death. Baseline screening process and recording done including Detail clinical history, Thorough clinical examination, Routine blood investigation-blood group, complete blood count, kidney function test, liver function test, blood sugar level, lipid profile Electrocardiogram (ECG).

Procedure of data collection: After applying inclusion and exclusion criteria total cases were studied. Data was collected from cases with proforma on admission till discharge from ICCU or death. Detailed case proforma used which is already validated by department faculties for entering all details of patient. After written valid informed consent of patient and her relatives, case proforma filled with all details like basic demographic data name, age, sex, clinical features on arrival, previous significant histories contributing to the present condition (DM / HTN / H/o old MI), habits like smoking / alcoholism are recorded. After initial diagnosis, details regarding the status of the patient on admission with respect to vitals, killip's classification and ECG.

The samples were categories by using blood pressure by using American college of cardiology

/ American heart association hypertension guidelines. 
Analysis of data is done using SPSS Inc., (Statistical Program for Social Science Inc.,) Chicago, IL, USA, version 20. Qualitative variables were expressed as frequency and percentage. Chi-square test, Logistic Regression, ANNOVA was used to compare qualitative variables. Level of significance "P" value was evaluated, where $\mathrm{P}$ value $<0.05$ was considered statistically significant. Multivariable logistic regression analysis was done to identify independent risk factors for mortality.

\section{Results}

A study of early \& late thrombolytic therapy in patients with acute STEMI studied in 200 cases. Data were analysed using computer based SPSS software by frequency, percentage etc. The pvalue $<0.05$ was considered as statistically significant.

Table 1: Distribution of cases according time of initiation of therapy

$$
\mathrm{n}=\mathbf{2 0 0}
$$

\begin{tabular}{|l|c|c|c|}
\hline \hline S.N. & Time & No. of cases & Percentage \\
\hline 1 & $<6$ hours (Early) & 108 & 54.00 \\
\hline 2 & $>6$ hours (Late) & 92 & 46.00 \\
\hline
\end{tabular}

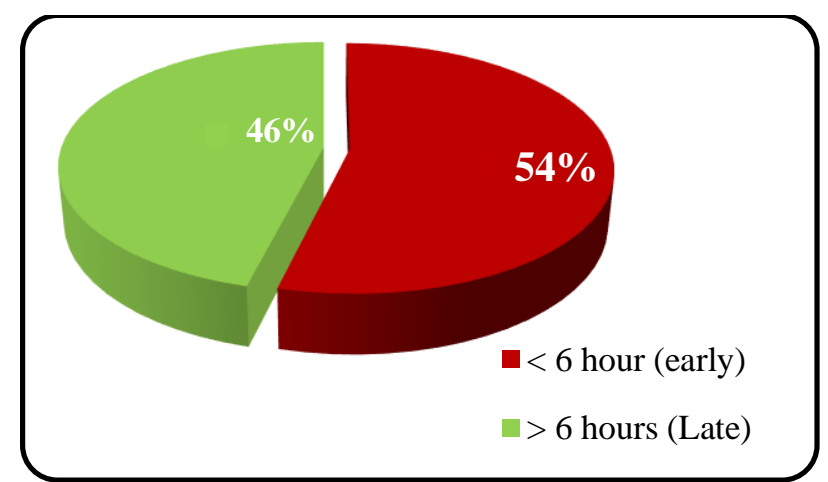

Fig. 1: Cases acc. to time of thrombolytic therapy

In present study of 200 samples maximum number of cases $108(54 \%)$ were received thrombolytic therapy before 6 hours from attack of AMI, whereas $92(46 \%)$ cases were received therapy after 6 hours from initial attack of AMI.
In present study of 200 samples, maximum number of cases 74 (37\%) went in cardiogenic shockinspite of thrombolytic therapy.

Table2: Correlation of individual complication with ST segment resolution

\begin{tabular}{|c|c|c|c|c|c|}
\hline \multirow{3}{*}{ Complication } & \multicolumn{5}{|c|}{$n=200$} \\
\hline & $\begin{array}{l}\text { ST s } \\
\text { rest }\end{array}$ & $\begin{array}{l}\text { gment } \\
\text { ution }\end{array}$ & $\begin{array}{c}\text { Od } \\
\text { ds }\end{array}$ & $\begin{array}{c}95 \% \\
\text { confide }\end{array}$ & p- \\
\hline & $\stackrel{<}{50 \%}$ & $>\mathbf{5 0 \%}$ & $\begin{array}{c}\text { rat } \\
\text { io }\end{array}$ & $\begin{array}{c}\text { nce } \\
\text { interval }\end{array}$ & e \\
\hline $\begin{array}{l}\text { Cardiogenic } \\
\text { Shock }\end{array}$ & $\begin{array}{c}39 \\
(19.5 \\
\%)\end{array}$ & $\begin{array}{c}35 \\
(17.5 \\
\%)\end{array}$ & $\begin{array}{c}0.3 \\
5\end{array}$ & $\begin{array}{c}0.19- \\
0.63\end{array}$ & $\begin{array}{c}0.00 \\
1\end{array}$ \\
\hline $\mathrm{CCF}$ & $\begin{array}{c}26 \\
(13.0 \\
7 \%) \\
\end{array}$ & $\begin{array}{c}29 \\
(14.57 \\
\%) \\
\end{array}$ & $\begin{array}{c}0.5 \\
4\end{array}$ & $\begin{array}{c}0.29- \\
1.02\end{array}$ & $\begin{array}{c}0.05 \\
7\end{array}$ \\
\hline Arrhythmias & $\begin{array}{c}16 \\
(8 \%)\end{array}$ & $\begin{array}{c}14 \\
(7 \%)\end{array}$ & $\begin{array}{c}0.4 \\
5\end{array}$ & $\begin{array}{c}0.21- \\
0.99\end{array}$ & $\begin{array}{c}0.04 \\
8\end{array}$ \\
\hline
\end{tabular}

In present study of 200 samples, correlation between complication and ST segment resolutionshows that in ST segment resolution > $50 \%$ shock $35(17.5 \%)$ was seen inmost of cases followed by CCF 29 (14.57\%). Similarly in ST segment resolution $<50 \%$ shock $39(19.5 \%)$ was seen as most of cases followed by CCF 26 $(13.07 \%)$.

It was found that there was significant correlationbetween ST segment improvement and complication such as CCF, arrhythmias and shock $(\mathrm{p}<0.05)$.

In present study of 200 samples, correlation between complication and time of initiation of thrombolytic therapy shows that in $<6 \mathrm{hrs}$. of initiation of therapy shock $23(11.5 \%)$ was seen. Similarly in initiation of thrombolytic therapy shows that in $>6$ hrs. of initiation of therapy shock $32(16 \%)$ was seen as most of cases

It was found that there was significant correlationbetween of initiation of therapy and complication such as cardiogenic shock ( $\mathrm{p}<$ $0.05)$.

\section{Discussion}

About the complication after receiving thrombolytic therapy $37 \%$ were in cardiogenic shock. 
Table 3: Complication

\begin{tabular}{|c|c|c|c|c|}
\hline Study & $\begin{array}{c}\text { Present } \\
\text { study }\end{array}$ & $\begin{array}{l}\text { Schroder } \\
\text { et al. }\end{array}$ & $\begin{array}{c}\text { Anders } \\
\text { on } \\
\text { et al. }{ }^{13}\end{array}$ & $\begin{array}{c}\text { Karthik } \\
\text { S. }^{14}\end{array}$ \\
\hline Year & 2019 & 1995 & 2002 & 2014 \\
\hline Place & -- & Germany & USA & $\begin{array}{c}\text { Tamilna } \\
\text { du }\end{array}$ \\
\hline $\begin{array}{l}\text { Sample } \\
\text { size }\end{array}$ & 200 & 6010 & 2352 & 60 \\
\hline $\begin{array}{l}\text { Study } \\
\text { type }\end{array}$ & $\begin{array}{c}\text { observatio } \\
\text { nal }\end{array}$ & $\begin{array}{l}\text { Prospecti } \\
\text { ve }\end{array}$ & $\begin{array}{c}\text { GUSTO } \\
\text {-III } \\
\text { TRIAL }\end{array}$ & $\begin{array}{c}\text { Cross } \\
\text { sectional }\end{array}$ \\
\hline $\begin{array}{l}\text { Cardiogen } \\
\text { ic Shock }\end{array}$ & $37 \%$ & $2.6 \%$ & $2.2 \%$ & $0 \%$ \\
\hline
\end{tabular}

\section{Conclusion}

Complication like cardiogenic shock were significantly less in patients thrombolysed within 6 hours of onset of chest pain compared to those who thrombolysed after 6 hours.

\section{References}

1. Schroder K. Extent of ST segment deviation in single ECG lead 90 minutes after thrombolysis as a predictor of medium term mortality in acute MI. Lancet $2001 ; 358: 14: 79-86$.

2. Farrer M. Change in ST segment elevation 60 min after thrombolytic initiation predicts clinical outcome accurately as later electrocardiographic changes. Heart 1997;78:461-71.

3. Anthon K. Prognostic clinical significance of ST segment potential determined by body surface mapping in patients with acute myocardial infarction. Circulation 1987;76(2):287.

4. Resolution of ST-Segment Elevation in Acute Myocardial Infarction- Early Prognostic Significance after Thrombolytic Therapy Results from the COBALT Trial Joerg Carlsson 1, Uwe Kamp 2, Dirk H irtel 2, Johannes Brockmeier 2, Rainer Meierhenrich 3, Sinisa Miketic 2, Sabine Walter 2, Frans van de Werf 4, Ulrich Tebbe 2

5. Gruppo Italiano per lo Studio della Streptochinasinell' Infarto Miocardico
(GISSI). Effectiveness of intravenous thrombolytic treatment in acute myocardial infarction. Lancet 1986;i:397-402

6. 2 ISIS-2 (Second International Study of Infarct Survival) Collaborative Group. Randomised trial of intravenous streptokinase, oral aspirin, both, or neither among 17,187 cases of suspected acute myocardial infarction: ISIS-2. Lancet 1988;ii:349-60

7. Santoro GM, Valenti R, Buonamici P, et al. Relation between STsegment changes and myocardial perfusion evaluated by myocardial contrast echocardiography in patients with acute myocardial infarction treated with direct angioplasty. Am J Cardiol1998;82:932-7

8. Schroder R, Dissmann R, Bruggemann T, et al. Extent of early ST segment elevation resolution: a simple but strong predictor of outcome in patients with acute myocardial infarction. J Am Coll Cardiol 1994; 24:384-91

9. Barbash GI, Roth A, Hod H, et al. Rapid resolution of ST elevation and prediction of clinical outcome in patients undergoing thrombolysis with alteplase (recombinant tissue-type plasminogen activator): results of the Israeli Study of Early Intervention in Myocardial Infarction. $\mathrm{Br}$ Heart J 1990;64:241-7

10. Anderson RD, White HD, Ohman EM, et al. Predicting outcome after thrombolysis in acute myocardial infarction according to ST-segment resolution at 90 minutes: a substudy of the GUSTO-III trial. Global Use of Strategies to Open occluded coronary arteries. Am Heart J 2002; 144:81-8

11. Antman EM, Anbe DT, Armstrong $\mathrm{P}$ et al. ACC/AHA guidelines for the management of patients with ST-elevation myocardial infarcion - executive summary. Circulation 2004;110:588-636. 
12. Van de Werf F, Ardissino D, Betriu A et al. Management of acute myocardial infarction in patients presenting with STsegment elevation. The Task Force on the Management of Acute Myocardial Infarction of the European Society of Cardiology. Eur Heart J 2003;24:28-66.

13. Anderson RD, White HD, Ohman EM, et al. Predicting outcome after thrombolysis in acute myocardial infarction according to ST-segment resolution at 90 minutes: a substudy of the GUSTO-III trial. Global Use of Strategies to Open occluded coronary arteries. Am Heart J 2002; 144:81-8.

14. S., Karthik; Surendran, Satchi A.; A., Mohamed Kasim. Efficacy of thrombolytic therapy with IV streptokinase in acute ST elevation myocardial infarction patients International Journal of Advances in Medicine, [S.1.], v. 6, n. 4, p. 1121-1124, july 2019. ISSN 2349-3933. 